\title{
Rediscovery of Curcuma sumatrana (Zingiberaceae) endemic to West Sumatra
}

\author{
M. Ardiyani ${ }^{1}$, A. Anggara ${ }^{2}$, J. Leong-Škorničková3
}

\section{Key words}

endemic Curcuma

ethnobotany

Ginger

Indonesia

lectotype

Pariaman

West Sumatra

\begin{abstract}
A recent exploration of Sumatra resulted in the re-collection of Curcuma sumatrana, an endemic Zingiberaceae species of unclear identity that was first described by Miquel nearly 150 years ago. The history of this species is discussed, a detailed description with a colour plate is provided and a lectotype is designated. Curcuma sumatrana currently qualifies under IUCN assessment as vulnerable, but due to the decline of its habitat, it is likely to fulfil the criteria as endangered in near future. As there is no comprehensive revision of the family Zingiberaceae for Sumatra in progress, it is meanwhile important to make accessible the characteristics of this endemic species to facilitate its proper identification and conservation management.
\end{abstract}

Published on 26 January 2011

\section{INTRODUCTION}

When reading the early taxonomic literature on Zingiberaceae, it is often difficult to get a clear picture of the identity of species due to brief and sometimes misleading descriptions. These descriptions were often based on few collections without consulting the type or the type was fragmentary. In addition, misleading synonymies were established without access to living material. This led to much confusion, particularly in the genus Curcuma (Leong-Škorničková et al. 2008a, b). Numerous earlydescribed species, particularly those from more remote areas, have not been re-collected recently, and their morphology is either completely unknown or they are considered synonyms of some commonly cultivated taxa.

During the exploration of West Sumatra, an interesting Curcuma species with orange-red inflorescences was collected in the wild at two different localities (A. Anggara \& R. Burlis 59 and $M$. Ardiyani et al. 189). At first glance, the bright orange-red inflorescence resembled that of Curcuma roscoeana Wall. from which it differs in the arrangement of bracts, which are not in pronounced vertical rows but in spiral. Closer examination of the flower revealed more differences, particularly in the structure of the anther, that has two spurs and no crest and also by the shape and colour of labellum (for comparison see colour plate of C. roscoeana in Škorničková \& Sabu 2005). Further study of the protologues of Curcuma species described from the Malesian region yielded an unproblematic match with the incomplete description of $C$. sumatrana. In addition, unlike many other Curcuma species, no drawings, paintings or photographs were ever published, adding to the unclear identity of this species.

Curcuma sumatrana was originally described by Miquel (1861) in a supplement to his 'Flora van Nederlandsch Indië' based

\footnotetext{
Herbarium Bogoriense, Research Centre for Biology, Indonesian Institute of Sciences (LIPI), JI. Raya Bogor km.46, Cibinong 16911, Java, Indonesia; corresponding author e-mail: marlina.ardiyani@lipi.go.id.

2 Universitas Andalas Herbarium, Kampus Limau Manis, Padang 25163. Sumatra, Indonesia.

3 The Herbarium, Singapore Botanic Gardens, 1 Cluny Road, 259569 Singapore.
}

on a specimen collected by Diepenhorst in Priaman, West Sumatra (at a distance of $20-40 \mathrm{~km}$ from our recent collections). The Latin description consists of nine lines outlining the basic features of which the most informative characters are: oblique rhizomes, usually two leaves on whole plant with long petioles and a terminal inflorescence with loosely arranged bracts that are pale or yellow at the base and red at the top.

The next short note on this taxon appeared some 20 years later in Gardeners' Chronicle where Brown (1882) explained that C. sumatrana had been introduced by Mr. Curtis from Sumatra into Messrs. Veitch nurseries and that a specimen was donated to Kew herbarium. The note also includes a brief description in English that fits Miquel's original description. Three specimens are present in Kew herbarium. One seems to be an original Curtis collection, while the other two are specimens made in 1882 and 1884 from material cultivated in Messrs. Veitch's nursery; the former is annotated by Brown and served the basis for his Gardener's Chronicle article. It is known that Curtis collected between 1880 and 1882 in Padang Highlands in West Sumatra, which is not far from the type locality of $C$. sumatrana and falls into current distribution range of the species.

In 1899, Schumann placed C. sumatrana as a synonymy of $C$. viridiflora Roxb. based on the descriptions, but in his comprehensive treatise of the Zingiberaceae in 1904 he realized that $C$. viridiflora is a taxon possibly synonymous with $C$. longa and then treats $C$. sumatrana as a separate species. He merely quoted parts of Miquel's description and noted that the description is imperfect and that he was unable to trace an original specimen, implying that he was not clear about the identity of $C$. sumatrana.

Ridley (1899) thought that C. sumatrana was a synonym of C. zedoaria. Later, Valeton surmised that the shape of the bract made Ridley think this, and in his account (Valeton 1918) C. sumatrana was placed under "incompletely known species". He examined the specimen from Diepenhorst No. 1327 in BO and commented that $C$. sumatrana is closely allied to $C$. petiolata, but did not mention that this was the type specimen. Since then, no other author has paid attention to this species.

During revisions of Curcuma material in numerous herbaria, several sheets of this taxon have been discovered at ANDA,

(c) 2011 Nationaal Herbarium Nederland

You are free to share - to copy, distribute and transmit the work, under the following conditions:

Attribution: $\quad$ You must attribute the work in the manner specified by the author or licensor (but not in any way that suggests that they endorse you or your use of the work).

Non-commercia:

You may not use this work for commercial purposes.

For any reuse or distribution, you must make clear to others the license terms of this work, which can be found at http://creativecommons.org/licenses/by-nc-nd/3.0/legalcode. Any of the above conditions can be waived if you get permission from the copyright holder. Nothing in this license impairs or restricts the author's moral rights. 
$\mathrm{BO}, \mathrm{E}$ and $\mathrm{K}$, but all were either unidentified or misidentified as other Curcuma species. On the other hand, several specimens from Sumatra collected by Lörzing (Lörzing 12603, L, Lörzing $5775, \mathrm{BO}, \mathrm{L})$ that are identified as $C$. sumatrana, are collections of some cultivated Curcuma species, most probably C. viridiflora.

Since the original description is incomplete and in Latin only, we include here an amended English description of the taxon accompanied by a colour plate.

Miquel in his original 1861 description mentions "Sumatra occid. in Priaman (D.)". This refers to a collection by Diepenhorst, but a collection number is not mentioned. We believe that specimen 1327 H.B. collected by Diepenhorst in Priaman (deposited at $\mathrm{BO}$ ) represents the original material and propose it as a lectotype.

\section{Curcuma sumatrana Miq. — Plate 1}

Curcuma sumatrana Miq. (1861) 615. - Type: Diepenhorst [1327 H.B.] (lecto, designated here, Acc. No. BO 0083511), Indonesia, Sumatra Occ. In Priaman.

Terrestrial herb, to $135 \mathrm{~cm}$ tall. Rhizome ovoid, up to $3 \mathrm{~cm}$ long and $2 \mathrm{~cm}$ wide, with a single branch, which turns into another main rhizome parallel to the previous one, externally cream white with pink tinge, internally light purple with cream borders and a purple line in between outer and inner part, aromatic. Root tubers not seen. Leafy shoot usually with 2 leaves, base c. $2.5 \mathrm{~cm}$ diam, pinkish white, pseudostem 3-50 cm long, with $2-4$ sheathing bracts, $25-34 \mathrm{~cm}$ long, pinkish white near base, reddish brown above, pubescent; ligule $3 \mathrm{~mm}$ long, deeply bilobed, reddish brown, densely hairy; petiole 29-36 $\mathrm{cm}$ long, reddish brown near base, green towards the lamina, winged, shortly hairy; lamina $57-64$ by $24-30 \mathrm{~cm}$, elliptic, plicate (clearly seen as hard veins in dry specimens), adaxially dark green, glabrous with hairs along side of the main veins, abaxially pale green with a maroon tinge towards the margin, glabrous, base acute, apex caudate, midrib green. Inflorescence terminal, appearing centrally from the middle of leafy shoot, $20-40 \mathrm{~cm}$ long. Peduncle $4-18 \mathrm{~cm}$ long, erect, white with reddish tinge. Spike $14-25$ by $5.5-7 \mathrm{~cm}$, cylindrical, consisting of $15-29$ bracts. Coma inconspicuous, uppermost $4-5$ sterile bracts are similar in colour and shape to fertile bracts, uppermost $2-3$ bracts are smaller and lighter in colour. Fertile bracts ovate-elliptic with rounded apex, c. $6-6.5$ by $5-6.5$ $\mathrm{cm}$, bright red, gradually becoming yellowish cream at base, connate in the lower half, shortly hairy on both sides. Cincinni with 3-5 flowers. Bracteoles one per flower, c. $13 \mathrm{~mm}$ long, translucent white. Flowers c. $6.5 \mathrm{~cm}$ long. Calyx c. $13 \mathrm{~mm}$ long, translucent white, obscurely 3-toothed, unilaterally split $4 \mathrm{~mm}$ from apex. Floral tube $4.1-4.4 \mathrm{~cm}$ long, white, glabrous; dorsal corolla lobe c. 18 by $9 \mathrm{~mm}$, translucent white, triangularly ovate, concave, mucronate, mucro 2-3 mm long, glabrous, lateral corolla lobes c. 17 by $7 \mathrm{~mm}$, translucent white, triangular with rounded, slightly concave apex, glabrous. Labellum 1.5 by $1.7 \mathrm{~cm}$, slightly emarginate, incision to $2 \mathrm{~mm}$, light yellow with dark yellow median band. Lateral staminodes c. 11 by $5 \mathrm{~mm}$, light yellow, glabrous. Anther versatile 8 by $3 \mathrm{~mm}$, yellowish white; filament $3 \mathrm{~mm}$ long, $5.5 \mathrm{~mm}$ broad at base, $2 \mathrm{~mm}$ broad at upper part; anther thecae c. $6 \mathrm{~mm}$ long, whitish, dehiscing longitudinally the entire length of theca, anther spurs $3 \mathrm{~mm}$ long, anther crest absent. Ovary trilocular, $2.5-3$ by $2.5 \mathrm{~mm}$, white, hairy in upper part. Epigynous glands 2, 2-3 mm long, cream, glabrous. Style $5 \mathrm{~cm}$ long, white, stigma white, ostiole not cilliate. Infructescence 1 fruit per bract, fruit a dehiscent capsule, ovoid, c. 2 by $1.1 \mathrm{~cm}$, white with red tinge. Seeds elliptic, 6 by $5 \mathrm{~mm}$, dark brown, aril translucent white, laciniate.
Distribution \& Ecology - Endemic to West Sumatra, known only from Maninjau, Sianok, Lembah Anai, Kayu Tanam, and Ulu Gadut from the Barisan Range. No data on habitat preference are available for the early collections, but recent collections originate from secondary forests at elevations between 100-500 m, often with many Laportea sp. (Urticaeae). This raises a question whether $C$. sumatrana is native to Sumatra. Unlike numerous vegetatively reproducing polyploid Curcuma species, which may be found naturalized all over Asia, the majority of seed-setting species from the subg. Curcuma are rather restricted in their distribution. They may colonize secondary habitats, but will not naturalize easily out of their natural range. Curcuma sumatrana is a seed-setting species (formation of fruits observed) and in spite of our extensive revision of Curcuma herbarium material (Leong-Škorničková et al. 2010) the species has not been found outside West Sumatra. We therefore believe that this species is native to Sumatra.

Phenology - Flowering May to September; fruiting observed from July onwards.

Vernacular name - Koenih Bimbo; Kamuniang (Maninjau).

Uses - Leaves are used for wrapping the flesh of durian fruit, which is then fermented to make a cooking ingredient called Pekasam. The water from boiled leaves is used to cure skin problems (itchiness).

IUCN assessment - The area of distribution of C. sumatrana is about $1600 \mathrm{~km}^{2}$ and consists of less than 10 localities, mainly in the Barisan Mountain range (between Maninjau Lake and Ulu Gadut). Based on the IUCN Red List criteria (IUCN 2001), we propose a conservation status of Vulnerable (VU $\mathrm{B} 1 \mathrm{ab}(\mathrm{iii}))$. However, as the habitat of $C$. sumatrana is affected by human activities and is in decline, the taxon is likely to qualify in the near future for the Endangered category.

Specimens examined. INDONESIA, West Sumatra, Kabupaten Agam, Kecamatan Tanjung Raya, Kanagarian Koto Malintang, Maninjau, Labuah Baru (0¹8.144'S, $\left.100^{\circ} 07.918^{\prime} \mathrm{E}\right), 1210 \mathrm{ft}, 8$ July 2009, flowering and fruiting, M. Ardiyani, Ari Anggara \& Pitra Akhriadi 189 (ANDA, BO, E); Western Maninjau, Muko-muko, small hill behind Field Research Station of Andalas University, 500 m, 11 Sept. 1984, M. Hotta \& T. Kohyama 356 (ANDA); Maninjau, about $60 \mathrm{~km}$ west from Bukittinggi, Muko-muko, Gunung Datar, 12 May 1984, Asmiati 73 (BO); ibidem, s.d., Roma Yuliet s.n. (ANDA); ibidem, 240-340 m, s.d., Reno Budi 110 (ANDA); Bukittinggi, Siniok, 21 Oct. 1989, Laivia Syarana 027 (ANDA); Kabupaten Pariaman, Sipisang Kayu Tanam, about 55 km north from Padang city, 150-450 m, 25 May 1995, Nofrida 64 (ANDA); ibidem, 26 May 1995, Andan 72 (ANDA); ibidem, 25 May 1995, Irma Suryani 34 (ANDA); ibidem, 26 May 1995, Irma Suryani 50 (ANDA); ibidem, 25 May 1995, Efdar Roza 19 (ANDA); ibidem, 29 Nov. 1992, Isman Afandi 21 (ANDA); Kabupaten Tanah Datar, Kecamatan X Koto, Cagar Alam Lembah Anai, 400-800 m, 1 June 2008, flowering, Ari Anggara \& Rikinovtian Burlis 59 (ANDA); Asam Pulau about 9 km from Lubuk Alung, 1 Nov. 1991, Mesli 084 (ANDA); along river of Asam Pulau about $9 \mathrm{~km}$ from Lubuk Alung, 3 Nov. 1991, Childa 12 (ANDA); Kabupaten Padang Pariaman, Lubuk Alung, Asam Pulau, 60-250 m, 22-24 Mar. 2002, Ade, Rizki, Indah, Icha, Lenmar \& Yessi AP-08-027 (ANDA); Padang, Ulu Gadut, along Sungai Gadut Gadang, 350-450 m, 2 Aug. 1984, M. Hotta, H. Okada \& T. Kohyama 281 (ANDA); Sumatra, sine loc. [presumably Padang Highlands], Curtis $115(\mathrm{~K})$; culta Hort. Veitch. (from Curtis), Aug. 1882, s.n. (K); culta Hort. Veitch. (from Curtis), 3 Sept. 1884, s.n. (K).

Note - Description and measurements based on living material Ardiyani et al. 189.

Acknowledgements The grant for fieldwork of the first author to Sumatra was funded by Directorate General of Higher Education Indonesia (DIKTI), Ministry of National Education (MENDIKNAS), 'Sinergi Penelitian dan Pengembangan Iptek Program Insentif Riset untuk Peneliti dan Perekayasa 2009' Programme. The research of the last author is funded by National Parks Board, Singapore and the Czech Science Foundation GAČR (grant no. 521/09/0202 and P506/10/0623. We also thank the curators of ANDA, BO, $E$ and $K$ for letting us examine specimens in their care. We thank Nurainas (ANDA) for various help during the course of our work. The Asian Zingiberaceae Information Centre in Singapore Botanic Gardens is acknowledged 

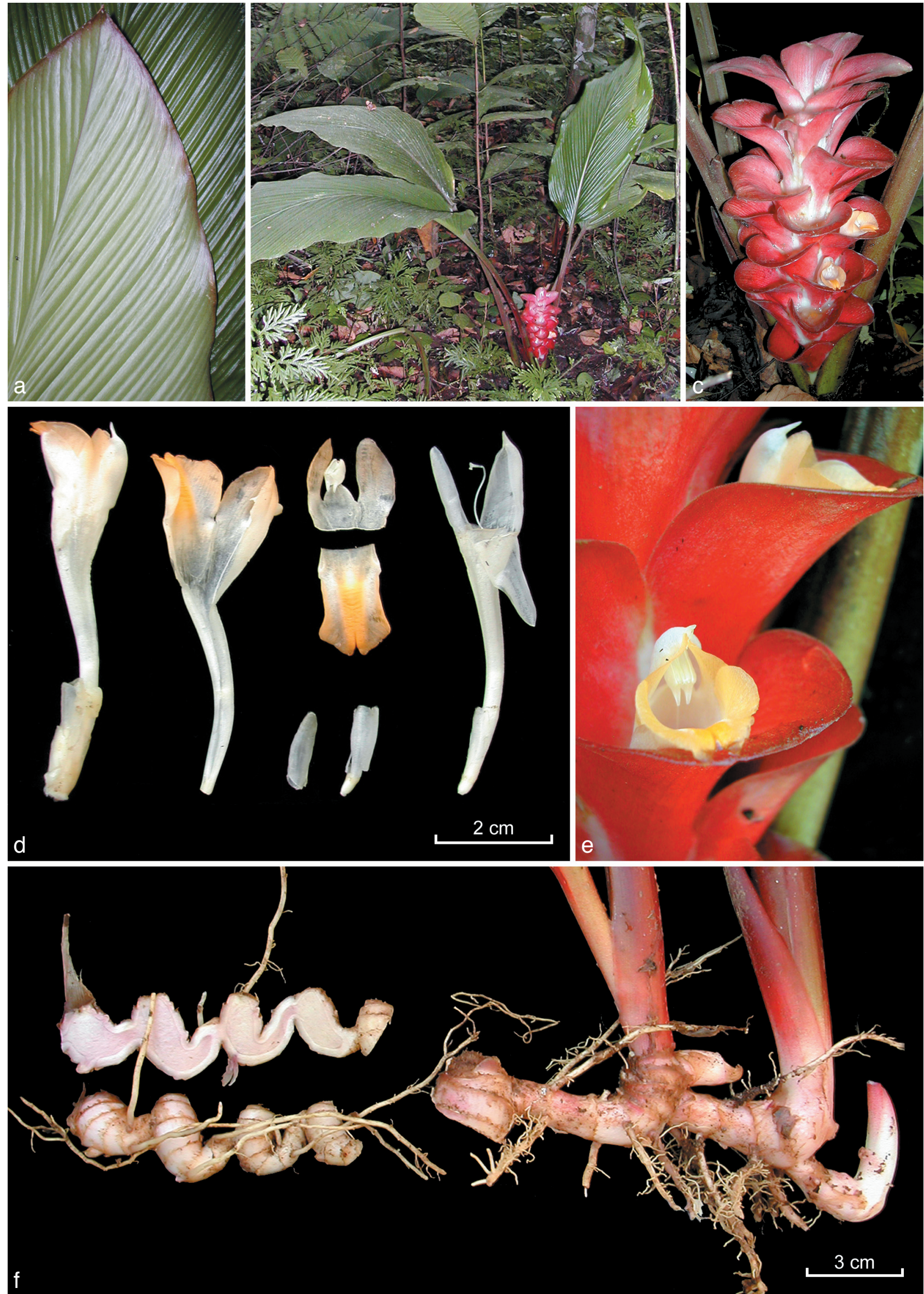

Plate 1 Curcuma sumatrana Miq. a. Abaxial and adaxial side of leaves; b. habit; c. inflorescence; d. flower dissection; e. flowers in bracts; f. rhizomes (all: M. Ardiyani et al. 189). — Photos by M. Ardiyani. 
for help in sourcing related references. The linguistic help with English from Dr. Gillian Dean and comments of an anonymous reviewer are greatly appreciated.

\section{REFERENCES}

Brown NE. 1882. Curcuma sumatrana. Miq. Gardeners' Chronicle September 1882: 393.

IUCN. 2001. IUCN Red List Categories and Criteria, Version 3.1. IUCN Species Survival Commission. Gland, Switzerland and Cambridge, UK.

Leong-Škorničková J, Šída O, Marhold K. 2010. Back to types! Towards stability of names in Indian Curcuma L. (Zingiberaceae). Taxon 59: 269282

Leong-Škorničková J, Šída O, Sabu M, Marhold K. 2008a. Taxonomic and nomenclatural puzzles in Indian Curcuma: the identity and nomenclatural history of C. zedoaria (Christm.) Roscoe and C. zerumbet Roxb. Taxon 57: 949-962.
Leong-Škorničková J, Šída O, Wijesundara S, Marhold K. 2008b. On the identity of turmeric: the typification of Curcuma longa L. (Zingiberaceae). Botanical Journal of the Linnean Society 157: 37-46.

Miquel FAW. 1861. Flora van Nederlandsch Indië, Eerste Bijvoegsel. Amsterdam, The Netherlands.

Ridley HN. 1899. The Scitamineae of the Malay Peninsula. Journal of the Straits Branch of the Royal Asiatic Society 32: 85-184.

Schumann K. 1899. Monographie der Zingiberaceae von Malaisien und Papuasien. Botanische Jahrbücher für Systematik, Pflanzengeschichte und Pflanzengeographie 27: 259-350.

Schumann K. 1904. Zingiberaceae. In: HGA Engler (ed), Das Pflanzenreich IV, vol. 46. Leipzig, Germany.

Škorničková J, Sabu M. 2005. Curcuma roscoeana Wall. (Zingiberaceae) in India. Gardens' Bulletin Singapore 57: 187-198.

Valeton TH. 1918. New notes on the Zingiberaceae of Java and the Malayan Archipelago. Bulletin du Jardin Botanique de Buitenzorg ser. 2, 27 : $1-167$. 